\title{
The Use of Radio Advertorials in Spanish Radio Stations*
}

\section{Salvador Perelló-Oliver ${ }^{1}$ Clara Muela-Molina²}

Recibido: 25/02/2018

Aprobado por pares: 14/06/2018
Enviado a pares: 28/02/2018

Aceptado: 21/09/2018

DOI: 10.5294/pacla.2019.22.3.7

Para citar este artículo / to reference this article / para citar este artigo

Parelló-Oliver, S. \& Muela-Molina, C. (2019). The use of radio advertorials in Spanish

radio stations. Palabra Clave, 22(3), e2237. DOI: http://doi.org/10.5294/pacla.2019.22.3.7

\section{Abstract}

Radio advertorials (RA) are long advertisements broadcasted within the programming and executed by journalists to imitate editorial content. An analysis of their presence, use and characteristics confirms that journalists and radio owners are not rigorous in the application of the codes of conduct that regulate this advertising feature in Spain. This work focuses on these rules and propose a matrix of variables, such as time slot, product category, type of endorser, advertiser identification, format and copy text style, which identifies these inappropriate practices in the sample under study. The results show that RAs are more prevalent during time slots with higher audience ratings and in programs hosted by well-known radio personalities. Also, most RAs are embedded within the editorial content of programs and are formatted as interviews, and their copy style is informative.

\section{Keywords (Source: Unesco Thesaurus)}

Advertising; radio advertising; program content; editorial content; ethics; journalist; radio.

\footnotetext{
* This paper was financed by the Ministerio de Economía y Competitividad, Spain. "Proyectos de I+D+i, del Programa Estatal de Investigación, Desarrollo e Innovación Orientada a los Retos de la Sociedad (2015-2017)”. Project CSO2017-82267-R.

1 orcid.org/0000-0003-2655-440X. Universidad Rey Juan Carlos, España. salvador.perello@urjc.es

2 orcid.org/0000-0002-1344-8731. Universidad Rey Juan Carlos, España.clara.muela@urjc.es
} 


\section{El uso de publirreportajes de radio en emisoras de radio españolas*}

\section{Resumen}

Los radio advertorials (RA) son mensajes publicitarios de larga duración locutados por periodistas, que imitan el contenido editorial y se emiten dentro de los programas. A partir del análisis de su presencia, uso y características, se constata que los periodistas y responsables de las emisoras radiofónicas en España tienden a ser poco rigurosos en la aplicación de los códigos de conducta que regulan el uso de este recurso publicitario. Este trabajo se centra en esos principios éticos y propone una matriz de variables como franja horaria, categoría de producto, tipo de portavoz, identificación del anunciante, formato y estilo del cuerpo de texto, mediante las cuales se pueden identificar las prácticas inapropiadas en la muestra objeto de estudio. Los resultados muestran que los RA tienen una mayor presencia en los horarios de mayor audiencia y son realizados por las personalidades radiofónicas de mayor reconocimiento social. Asimismo, en la mayoría de los casos analizados, los RA se mezclan con el contenido programático, siendo la entrevista el formato más utilizado y el informativo, el estilo del cuerpo de texto con más presencia.

\section{Palabras clave (Fuente: tesauro de la Unesco)}

Publicidad; publicidad radiofónica; contenido de programa; contenido editorial; ética; periodista; radio.

* Este artículo fue financiado por el Ministerio de Economía y Competitividad, España. Proyectos de I+D+i, del Programa Estatal de Investigación, Desarrollo e Innovación Orientada a los Retos de la Sociedad (2015-2017). Proyecto CSO2017-82267-R. 


\section{0 uso de anúncios de rádio em estações de rádio espanholas}

\section{Resumo}

Os anúncios de rádio (AR) são mensagens publicitárias de longa duração relatadas por jornalistas, que imitam o conteúdo editorial e que são transmitidas nos programas. A partir da análise de sua presença, uso e características, observa-se que os jornalistas e responsáveis pelas emissoras de rádio na Espanha tendem a ser pouco rigorosos na aplicação dos códigos de conduta que regulam o uso desse recurso publicitário. Este trabalho concentra-se nesses princípios éticos e propõe uma matriz de variáveis, como fuso horário, categoria do produto, tipo de porta-voz, identificação do anunciante, formato e estilo do corpo do texto, através das quais é possível identificar práticas inadequadas na amostra em estudo. Os resultados mostram que os AR têm maior presença nos tempos de maior audiência e são realizados pelas personalidades de rádio de maior reconhecimento social. Da mesma forma, na maioria dos casos analisados, os AR são misturados com o conteúdo programático, sendo a entrevista o formato mais utilizado o informativo, o estilo de corpo de texto com mais presença.

\section{Palavras-chave (Fonte: tesauro da Unesco)}

Publicidade; publicidade de rádio; conteúdo do programa; conteúdo editorial; ética; jornalista; rádio.

* Este artigo foi financiado pelo Ministerio de Economía y Competitividad, Espanha. "Proyectos de I+D+i, del Programa Estatal de Investigación, Desarrollo e Innovación Orientada a los Retos de la Sociedad (2015-2017)”. Projeto CSO2017-82267-R. 
Radio spots are the predominant advertising format in commercial radio (Perelló-Oliver \& Muela-Molina, 2012). This type of advertisement is usually around 20 seconds long and broadcast during commercial breaks, clearly separated from the programming. Radio advertorials (RAs), on the other hand, are not recognizable as advertising and give the audience the impression that they are listening to independent editorial material (Baerns, 2003, p. 101), using an execution technique (Hausknecht, Wilkinson, \& Prough, 1991) that implies certain challenges regarding the content, form and context of the message.

Due to their purpose, nature and characteristics, RAs cannot be considered an advertising format. They have in fact been recognized by several authors as an advertising practice that breaches the established ethical and legal rules and have been described as "disguised advertising" (Kim, Pasadeos, \& Barban, 2001; Dix \& Phau, 2009; Balasubramanian, 1994), "camouflaged advertising” (Kim et al., 2001; Dix \& Phau, 2009), "hidden advertising" (Zhou, 2012), "covert communication" (Crook, 2004), or a category of misleadingness (disguised format) of masked marketing practices (Petty \& Andrews, 2008). Therefore, "advertorials are considered mixtures of advertising and editorial content" (Van Reijmersdal, Neijens, \& Smit, 2005, p. 41) and a modality of hybrid messages that "include all paid attempts to influence audiences for commercial benefit using communications that project a non-commercial character" (Balasubramanian, 1994, p. 30).

RA messages receive greater attention because they are disguised as editorial content (Baerns, 2003, p. 101) and they become more persuasive due to their hidden intentionality (Kim et al., 2001). In fact, RAs "could enhance message credibility because they covertly or overtly disguise their commercial origins" (Balasubramanian, 1994, p. 32). Additionally, advertorials as camouflaged advertisements "have also received considerable criticism because they have blurred the line between advertising and editorial content" (Kim et al., 2001, p. 265), a line rigidly established and clearly delineated traditionally to separate both types of contents (Sandler \& Secunda, 1993, p. 73). 
Another driving factor of this research raises important ethical/legal/ public policy questions concerning "the protection of legitimate interests of the individual (e.g., a person's desire to know-if, when, and by whomhe/she is being influenced with regard to a product)" (Balasubramanian, 1994, p. 30). In this respect, Nebenzhal and Jaffe (1998) argue that "the right to be informed is synonymous with the right to know if a message is sponsored" (p. 807) and, in the case of advertorials, as disguised advertising, "consumers are less able to apply defense mechanisms against the ad" (Nebenzhal \& Jaffe, 1998, p. 813), therefore paying attention to a masked communication without realizing its nature and which they might otherwise choose to ignore (Petty \& Andrews, 2008).

The advertising self-regulatory system in Spain is managed by the Asociación para la Autorregulación de la Comunicación Comercial [Association for the Self-regulation of Commercial Communication] (Autocontrol) whose Code of Conduct, in Article 13 on the principle of authenticity, demands that "[advertising will be identifiable as such whatever its form or medium used]" (Autocontrol, 2011, p. 4), a very general requirement and not at all descriptive of how this basic principle is to be fulfilled. The Consolidated Code of Advertising and Marketing Communication Practice of the International Chamber of Commerce (ICC) similarly describes the principle of identification in Article 8: "Marketing communications should be clearly distinguishable as such, whatever their form and whatever the medium used" (ICC, 2011, p. 8).

The majority of previous studies on advertorials have focused on print media and considered four different aspects: 1) analysis of presence, use, and compliance with guidelines for various executional characteristics of advertorials in magazines (Cameron, Pak, \& Kim, 1996; Ju-Pak, Kim, \& Cameron, 1995; Stout, Wilcox, \& Greer, 1989) and newspapers (Cameron \& Ju-Pak, 2000; Goodlad, Eadie, Kinnin, \& Raymond, 1997); 2) analysis of effectiveness and deceptiveness of newspaper (Hausknecht et al., 1991) and magazine advertorials (Kim et al., 2001; Van Reijmersdal et al., 2005); 3) analysis of the advertorial production process (Erjavec, 2004; Erjavec \& Kovačič, 2010; Eckman \& Lindlof, 2003; Poler Kovačič, 
Erjavec, \& Stularal, 2011); and 4) discourse analysis in newspapers (Erjavec, 2004; Zhou, 2012). Other studies have evaluated the attitudes of advertisers, editors and media practitioners towards advertorials (Cameron \& Curtin, 1995; Cameron \& Haley, 1992; Dix \& Phau, 2009; Sandler \& Secunda, 1993) or focused on other types of media, such as television, to analyze the effectiveness of infomercials (Martin, Bhimy, \& Agee, 2002; Singh, Balasubramanian, \& Chakraborty, 2000).

The present research has taken into account previous literature and adapted the variables used to radio as a medium of sound. In the absence of previous work found on the subject, this research considers RAs to be live communications subject to a commercial arrangement that often take the form of program content, between one and five minutes long, and broadcast within the program or between its different sections.

The use of advertorials and its compliance with guidelines must allow for various executional characteristics, such as labeling, sponsorship information (Cameron et al., 1996; Ju-Pak et al., 1995), copy text (Kim et al., 2001), and separation of advertisements from programming matter (Wilkinson, Hausknecht, \& Prough, 1995).

This paper adds to the literature by investigating the presence and use of advertorials in Spain in a medium not previously analyzed. The specific objectives of the research are: 1 ) to provide a theoretical and conceptual framework for the object of study in the radio medium;2) to quantify the presence of RAs; 3 ) to analyze their use based on the identification and conceptualization of certain components and factors; and 4) to ascertain compliance with the codes of conduct that regulate the content, form and broadcast of this type of advertising message.

\section{Theoretical Background and Research Questions}

Advertisements disguised as part of the programming or printed editorial content blur the distinction between advertising and editorial material (Cameron \& Haley, 1992). Content separation is a legal and ethical requirement as well as an illusory reality (Eckman \& Lindlof, 2003) that affects the credibility and involvement of media and advertisers (Ellerbach, 
2004; Ju-Pak et al., 1995; Sandler \& Secunda, 1993). Nonetheless, advertisers are more receptive to advertorial practice and less concerned about its potentially harmful effects, while journalists continue to express unease and resistance to these changes in media strategy (Cameron \& Curtin, 1995; Eckman \& Lindlof, 2003).

The questionable use of advertorials converges in their legal and deontological aspects. The practice implies a violation of consumer autonomy and his/her right to know (Nebenzhal \& Jaffe, 1998) and "intentionally attempts to hide the marketing context of the statements" (Petty \& Andrews, 2008 , p. 13). This infringement of the advertising principle of clear identification and separation of advertising and program contents is problematic and is a violation of the law (Baerns, 2003; Poler Kovačič \& Erjavec, 2010; Steininger \& Woelke, 2008). For Rozukalne, advertorials are an advertising media practice hidden within journalistic contents (especially in radio) that "indicates a breach of professional ethics, as well as infringement of several regulatory acts" (Rozukalne, 2012, p. 15). In this regard, the perceived potential for deception of an advertorial "results from the consumer's initial perception of the message as editorial" (Hausknecht et al., 1991, p. 43; Lacher \& Rotfeld, 1994).

The main objective of previous studies was to quantify the presence of advertorials (Cameron et al., 1996; Cameron \& Ju-Pak, 2000; Goodlad et al., 1997; Ju-Pak et al., 1995; Stout et al., 1989), although some research has also considered two further factors: location within programming ( JuPak et al., 1995; Cameron et al., 1996; Cameron \& Ju-Pak, 2000), and product category (Cameron et al., 1996; Cameron \& Ju-Pak, 2000; Ju-Pak et al., 1995), which leads to the following research question:

RQ1: What is the distribution of radio advertorials by time slot and product category?

Although advertisers are ultimately responsible for the content and form of their advertisements, the voice that conveys the message is an element that exercises great influence on listeners. Accordingly, in the production process of an advertisement, agencies decide on the source of the 
message - an important choice since, depending on its credibility, popularity and the level of listener trust in the endorser (Kertz \& Ohanian, 1992) the advertisement will be more or less effective and persuasive (Martin et al., 2002). Priester and Petty (2003) argue that, if a recipient "can be confident that an expert source will be willing to provide accurate information because of his or her high trustworthiness, they may forgo the effortful task of scrutinizing the message and, instead, unthinkingly accept the conclusion as valid" (p. 409), which is applicable to advertisements that simulate informative and programming contents. Buchholz and Smith (1991) take the same view when highly involved consumers are exposed to radio commercials - that is, the audience listens to the radio due to its high credibility, projected onto all contents. News personalities and sportscasters often attain celebrity status and are used to promote a product (Belch \& Belch, 2013), although their presence in magazine advertising is very low, barely $1 \%$. Thus, an endorsement is defined as

any advertising message (...) that consumers are likely to believe reflects the opinions, beliefs, findings, or experiences of a party other than the sponsoring advertiser, even if the views expressed by that party are identical to those of the sponsoring advertiser. (FTC, 2009, p. 53124)

Sponsor information is one of the cues that allow listeners to identify the advertiser and the commercial nature of the message, as analyzed in previous research (Cameron et al., 1996; Cameron \& Ju-Pak, 2000; Ju-Pak et al., 1995). These message characteristics provide the basis for the following research question:

RQ2: Which is the more prevalent endorser in radio advertorials?

RQ3: Is the sponsor's identification mentioned at the beginning of radio advertorials?

In radio spots, broadcast in commercial breaks separated from programming, most formats tend to imitate the information essence of the medium, so that in $18.7 \%$ of cases the advertisement replicates journalistic resources and includes a newscaster, interviewer or reporter, or imitates program contents such as competitions, audience call-ins, advisory 
programs, etc. (Muela-Molina, 2010). However, advertorials are broadcast live within the programming and tend to be similar in format to the program they are included in. RAs imitate the editorial style of talk shows and simulate journalistic contents, making it difficult for the audience to identify their commercial nature. This puts recipients in a vulnerable and unclear position regarding the ideas or information published by the media (Goodlad et al., 1997; Harro-Loit \& Saks, 2006) since advertisers are in complete control of advertorials (Rozukalne, 2012). This is against the principles of the codes of conduct of the sector since format and style are two elements that allow listeners to distinguish between contents, as analyzed for other forms of media (Goodlad et al., 1997; Martin et al., 2002; Stout et al., 1989). The style of copy text is closely connected to the format (Kim et al., 2001; Muela-Molina, 2012) and will be more or less persuasive, which leads to the following research questions:

RQ4: Which is the more prevalent format in radio advertorials?

RQ5: Which is the more prevalent copy text style in radio advertorials?

\section{Methodology}

\section{Sample}

The conception of this work and its objectives require quantitative research based on content analysis, i.e., "a research technique for the objective, systematic, and quantitative description of the manifest content of communication" (Berelson, 1952, p. 18). Data was taken from the Estudio General de Medios [General Media Study] (EGM) for the first months of the year (AIMC, 2016) to select the group of national commercial radio stations with highest audience ratings. Following an intentional strategic approach, the month chosen for obtaining data was June 2016 due to its high advertising volume, according to Infoadex, the annual study on investment in advertising in Spain.

Once the radio stations were identified, the sample was taken from those that broadcast nationally and in Spanish: Cadena Ser, Onda Cero, and 
Cadena Cope (generalist); C40, Dial, Europa FM, C100, Rock FM, Kiss FM, Máxima FM, Radio Olé and M80 (musical). The 24-hour programming of the 12 radio stations was recorded during four Monday to Friday weeks, in consecutive days (Tuesday, Wednesday, and Thursday), in an external storage device. The recordings were then analyzed for the registration and coding of variables using audio computer software (Sony Sound Forge Audio Studio 9.0).

The validity, generalizability and replicability of the sample (Neuendorf, 2002) is guaranteed as it includes the totality of RAs broadcast within a sample of commercial - therefore, private — radio stations of national coverage. In order to preserve the reliability of content analysis (Neuendorf, 2002), first a single coder carried out the active listening of the 288 hours of programming to locate and edit all RAs. In a second phase, two different coders analyzed the set, which included a total of 39 RAs, which were then coded with the following variables.

\section{Variables}

In the absence of previous work found on the subject, this research considers RAs to be live communications subject to a commercial arrangement that often take the form of program content, between one and five minutes long, and broadcast within the program or between its different sections. The literature review, framework on radio and advertising policies and research questions have been the basis for the operationalization of variables and their attributes.

- Radio station format. 1) generalist; and 2) music

- Time slot. Coinciding with the EGM classification, this variable has been characterized with the following attributes: 1) early morning (00:00h-05:59); 2) morning (06:00-11:59); 3) midday (12:00$15: 59)$; 4) evening (16:00-19:59); and 5) night (20:00-23:59)

- Product category. This work has used the list of 22 products/services used by Infoadex, the annual study on investment in advertising: 1) food; 2) cars; 3 ) drinks; 4) beauty and hygiene; 5) construction; 
6) culture, education, and media; 7) sports and leisure; 8) distribution and restaurants; 9) energy; 10) office equipment, electronics/ IT, and retail; 11) finance; 12) home; 13) industrial, work material, agriculture; 14) cleaning; 15) personal items; 16) health; 17) public and private services; 18) tobacco; 19) telecommunications and Internet; 20) textile and clothing; 21) transportation, travel, and tourism; and 22) miscellaneous

- Endorser. Voice that conveys the message and describes the product, operationalized with the following attributes: 1 ) radio personality, presenter or collaborator (a journalist working in certain fixed sections of the program as a guest, commentator or columnist); 2) sponsor: identified advertiser or anonymous spokesperson; 3) testimonial/expert; and 4) celebrity/others

- Advertiser identification. Following the fourth rule of identity (OfCom, 2011), the point in time in which the name of the brand or advertiser is mentioned for the first time. For the development of this variable, this first mention was identified in all cases and, subsequently, the average point in time (17.8") was calculated for the sample set. The variable included two attributes: 1) early mention: before the average; 2) late mention: after the average.

- Format. Advertorials can take the form of: 1) a newscast;2) an interview; and 3) a reportage

- Copy text style. This can be one of two types: 1) narrative - a story is told unrelated to the product concerned, although it becomes linked to it at a certain point; 2 ) informative - a detailed and objective description of the characteristics of the product, its manufacturing, components, uses, functions, etc.

\section{Results}

The analysis of RA distribution (Table 1) in response to RQ1 shows that products related to culture, education and the media have the highest presence $(20.5 \%)$, with a homogeneous distribution among the daytime slots of the programming. These are followed by health products, with a higher relative weight (15.4\%) concentrated in the morning and midday 
time slots. RAs concerning food, finance and distribution/restaurant products show the same relative weight $(10.3 \%)$. It is worth noting that all cases analyzed in the finance category are concentrated in the midday time slot.

\section{Table 1. Radio advertorials by product category and time slot}

\begin{tabular}{|c|c|c|c|c|c|c|}
\hline & $\begin{array}{c}\text { 00:00- } \\
05: 59\end{array}$ & $\begin{array}{c}06: 00- \\
11: 59\end{array}$ & $\begin{array}{c}12: 00- \\
15: 59\end{array}$ & $\begin{array}{c}16: 00- \\
19: 59\end{array}$ & $\begin{array}{c}20: 00- \\
23: 59\end{array}$ & Total \\
\hline \multirow{2}{*}{ Food } & .0 & 25.0 & 50.0 & 25.0 & .0 & 100.0 \\
\hline & .0 & 7.1 & 11.1 & 33.3 & .0 & 10.3 \\
\hline \multirow{2}{*}{ Culture, education, media } & .0 & 37.5 & 50.0 & 12.5 & .0 & 100.0 \\
\hline & .0 & 21.4 & 22.2 & 33.3 & .0 & 20.5 \\
\hline \multirow{2}{*}{ Sport and free time } & .0 & 33.3 & 33.3 & 33.3 & .0 & 100.0 \\
\hline & .0 & 7.1 & 5.6 & 33.3 & .0 & 7.7 \\
\hline \multirow{2}{*}{ Distribution and restaurants } & .0 & 75.0 & 25.0 & .0 & .0 & 100.0 \\
\hline & .0 & 21.4 & 5.6 & .0 & .0 & 10.3 \\
\hline \multirow{2}{*}{$\begin{array}{l}\text { Office equip., electr./ } \\
\text { IT and retail }\end{array}$} & .0 & 100.0 & .0 & .0 & .0 & 100.0 \\
\hline & .0 & 7.1 & .0 & .0 & .0 & 2.6 \\
\hline \multirow{2}{*}{ Finance } & .0 & .0 & 100.0 & .0 & .0 & 100.0 \\
\hline & .0 & .0 & 22.2 & .0 & .0 & 10.3 \\
\hline \multirow{2}{*}{ Health } & .0 & 50.0 & 50.0 & .0 & .0 & 100.0 \\
\hline & .0 & 21.4 & 16.7 & .0 & .0 & 15.4 \\
\hline \multirow{2}{*}{ Public and private services } & .0 & .0 & 100.0 & .0 & .0 & 100.0 \\
\hline & .0 & .0 & 16.7 & .0 & .0 & 7.7 \\
\hline \multirow{2}{*}{ Telecommunications and Internet } & .0 & .0 & .0 & .0 & 100.0 & 100.0 \\
\hline & .0 & .0 & .0 & .0 & 33.3 & 2.6 \\
\hline \multirow{2}{*}{ Textile and clothing } & .0 & .0 & .0 & .0 & 100.0 & 100.0 \\
\hline & .0 & .0 & .0 & .0 & 33.3 & 2.6 \\
\hline \multirow{2}{*}{ Transport, travel and tourism } & 33.3 & 33.3 & .0 & .0 & 33.3 & 100.0 \\
\hline & 100.0 & 7.1 & .0 & .0 & 33.3 & 7.7 \\
\hline \multirow{2}{*}{ Miscellaneous } & .0 & 100.0 & .0 & .0 & .0 & 100.0 \\
\hline & .0 & 7.1 & .0 & .0 & .0 & 2.6 \\
\hline \multirow{2}{*}{ Total } & 2.6 & 35.9 & 46.2 & 7.7 & 7.7 & 100.0 \\
\hline & 100.0 & 100.0 & 100.0 & 100.0 & 100.0 & 100.0 \\
\hline
\end{tabular}

Note: $X^{2}=61,428(44, N=39), p<.042$.

Source: Own elaboration. 
The results in Table 2 in response to RQ2 indicate that sponsors have greater weight $(51.3 \%)$ than radio personalities $(46.2 \%)$, while the presence of testimonials or experts is marginal and celebrities is non-existent. It is worth noting that the use of radio journalists as endorsers is more usual in musical radio than in generalist radio and that their involvement with the message is high, in some cases even guaranteeing the efficiency of the product or recommending it based on personal experience.

Table 2 also shows the data concerning the point in time in which the brand or product is mentioned for the first time (answer to RQ3). The reality is that in just over half of the cases the advertiser is identified at the beginning of the advertorial (51.3\%). However, disaggregating by type of endorser, when radio personalities execute the advertorial, the first mention of the product or brand is postponed in $63.2 \%$ of cases; meanwhile, when the endorser of the advertorial is the sponsor, the identification of the voice that describes the product or service is heard during the first few seconds of broadcast in $65 \%$ of cases.

Table 2. Endorser and advertiser identification

\begin{tabular}{|c|c|c|c|c|}
\hline & & \multicolumn{2}{|c|}{ Advertiser Identification } & \multirow{2}{*}{ Total } \\
\hline & & Early mention & Late mention & \\
\hline \multirow{6}{*}{ Endorser } & \multirow{2}{*}{ Radio personality } & 38.9 & 61.1 & 100.0 \\
\hline & & 30.4 & 68.8 & 46.2 \\
\hline & \multirow{2}{*}{ Sponsor } & 75.0 & 25.0 & 100.0 \\
\hline & & 65.2 & 31.3 & 51.3 \\
\hline & \multirow{2}{*}{ Testimonial/expert } & 100.0 & .0 & 100.0 \\
\hline & & 4.3 & .0 & 2.6 \\
\hline \multirow{2}{*}{\multicolumn{2}{|c|}{ Total }} & 59.0 & 41.0 & 100.0 \\
\hline & & 100.0 & 100.0 & 100.0 \\
\hline
\end{tabular}

Note: $\chi^{2}=5,820(2, N=39), p<.054$.

Source: Own elaboration.

Concerning the instant in which the brand or product is mentioned, after calculating the average point in time in which the brand or product is mentioned for the first time (17.8”), the reality is that, in nearly $60 \%$ of cases, the advertiser is identified at the beginning of the advertorial, i.e., at a point in time before the average. However, disaggregating by type of en- 
dorser, when radio personalities voice the advertorial, mentioning the product or brand is postponed to a point in time after the average in $61.1 \%$ of cases, while when the sponsor's spokesperson is the endorser of the advertorial, the identification of the voice that describes the product or service is heard during the first few seconds of broadcast in $75 \%$ of cases.

This evidence implies that, contrary to the principles established in the codes of conduct, the presenter and leader of the program who is directly responsible for its contents tends to delay as much as possible the warning that informs listeners of the commercial nature of the message, against his/ her professional duty. It is worth noting that the average point in time derived from the analysis of the sample (17.8\%) is much higher than what is required by current codes, i.e., that the first mention of the brand is broadcast as soon as possible, without delay and repeatedly in order to warn listeners of the advertising nature of the message.

The data shows that the most used format in these messages is the interview (43.6\%), followed by the news format (35.9\%), which answers $\mathrm{RQ} 4$. In this regard, it is usual for a radio journalist to interview the sponsor's spokesperson, whether a lawyer from a law firm or a doctor from a weight loss clinic, and therefore provide a seemingly rigorous and neutral background for the execution of the advertorial. On the other hand, in advertorials that imitate the news, a radio personality usually introduces real information directly or indirectly related to the product or service advertised. Finally, in the case of reportage, journalists themselves, showing quite a high level of involvement, describe and explain in detail the characteristics of the product or service, in some cases from the actual premises of the advertiser.

The copy text style used in advertorials is a key variable to understand the strategy followed by advertisers to gain the attention of consumers and to maintain their active listening. The narrative style describes, explains or informs about certain events or problems that eventually lead to the product or brand as a solution. For example, the discussion of cases published in the press that have a great impact on public opinion, broadcast live together with real testimonials or other aspects that can affect or affect lis- 
teners, leads to a solution provided by the advertiser who also analyzes its legal basis. Another example would be the scientific explanation of a clinical pathology. On the other hand, the informative style provides a detailed description of the product or service so that listeners have a supposedly better and more objective understanding of it. In this regard, the analysis of the sample answers RQ5 and confirms that informative RAs (82.1\%) predominate over narrative RAs (17.9\%).

\section{Discussion}

The present work focuses on the study of hybrid messages, an irresponsible practice that violates the rights of consumers by breaching the basic principles of commercial communication. RAs have received little attention from researchers even though the Spanish radio medium has a daily audience of 27,411,000 listeners (AIMC, 2016). On the basis of previous work, this study analyzes the presence and characteristics of RAs using and adapting variables analyzed for other types of media and adding new variables specific to the radio medium. However, there is an element that highlights the importance of this research. While the source of advertorials is not identified in print media - it is unknown-, RAs are executed by a voice and it is normally journalists themselves - radio presenters or collaborators - who lend their voices to the brands. In doing so, they compromise to a large extent their professional and information credibility.

The fact that the presence of RAs is concentrated in the morning time slots, which have the highest audience rates and feature the best known radio presenters, highlights the unethical behavior of radio owners and of journalists who collaborate in this advertising practice. In fact, although the latter are the more prevalent endorsers, they also collaborate in the execution of RAs when the endorser is the sponsor or an expert. In this case, although in a supporting role, the presenter acts as the host who interviews the endorser, and therefore becomes an essential part of the advertorial.

Journalists - in their role of radio presenter or collaborator-tend to postpone the identification of the advertiser so that listeners perceive programming continuity. On the other hand, when the endorser is a sponsor's 
spokesperson, the name of the brand is mentioned at the beginning of the message. This is because, on the whole, radio presenters introduce the advertiser at the beginning of the interview, imitating a journalistic format and camouflaging in this way the nature of the endorser and therefore the intentionality of the message. In this regard, one of the challenges of this research has been to establish the point in time in which a brand is mentioned for the first time. The empirical evidence indicates that presenters and directors of radio programs tend to delay warning listeners of the advertising nature of the communication, against their professional duty. The average point in time derived from the analysis of the sample (17.8”) is a lot higher than would be desirable to fulfill the principles of transparency and rule of identity - and consequently preserve listener rights - , since we understand that any advertising reference mentioned after 5 " from the beginning of the advertorial contradicts these principles.

Regarding the format used, the interview has the highest cumulative presence $(43.6 \%)$. The interviewee is personified by a voice identified with a name, surname and professional position in a company. However, it is usual practice to use a different person for each radio station, even when the message is practically the same. In these cases, journalists show great involvement with the advertised product or brand, provide basic corporate information and encourage the audience to contact the advertiser. In reportages $(20.5 \%)$, however, this involvement is characterized by a detailed and thorough description of the product or manufacturer and can include visiting the company's premises and broadcasting live information on site. The news format is used in $35.9 \%$ of advertorials and takes advantage of the interest of listeners in current affairs. The results also show that the predominant copy text style is informative, where the advertorial becomes camouflaged with editorial contents, highlighting the unethical behavior of journalists towards their audience in favor of advertisers whose products or services are mentioned 3 times or more in $50 \%$ of cases.

\section{Implications}

Radio owners should, for the benefit of listeners, apply self-disciplinary standards for the acceptance of advertising (Cameron \& Haley, 1992) since, as 
shown in this work and previous studies, the self-regulation of advertorial acceptance is not fully effective (Cameron \& Ju-Pak, 2000). "Regulatory issues should be concerned with what information is to be included in the content of camouflaged advertising to let the audience know it is a commercial” (Kim et al., 2001, p. 278). Therefore, legitimate journalists must not endorse products and should never be used as sources in RAs (Ellerbach, 2004). In this respect, "if reporters and editors were doing their job professionally and according to ethical standards, if they were not initiators and did not accept this practice, the advertorials would not be produced" (Poler Kovačič \& Erjavec, 2010, p. 391).

The main problem is that "the control mechanisms of legislation, the Code of Ethics and the idea of good journalistic practice are either being ignored or misused" (Harro-Loit \& Saks, 2006, p. 321). In this regard, the Code of Ethics of the American Society of Professional Journalists-more explicit than the Spanish one-establishes that, in order to preserve journalistic independence and avoid conflicts of interest, journalists must deny favored treatment to advertisers, distinguish news from advertising and shun hybrids that blur the lines between the two (Society of Professional Journalists, 2014), on the understanding that this type of unethical behavior can affect the credibility of the media and of journalists themselves (Muela-Molina, Martín-Santana, \& Reinares Lara, 2028; Perello-Oliver \& Muela-Molina, 2017).

\section{Limitations}

The limitations of this work basically concern the characteristics of the RA subsample. Although the analyzed set has been taken from a sample of the 12 radio stations with highest audience ratings, their entire 24 hour programming recorded throughout 4 Monday to Friday weeks in consecutive days, the relative weight of RAs as an advertising resource in the radio medium when compared to, for example, radio spots, remains very low. The subsample is significant for the development of an exploratory study but limited in terms of overall statistical representativeness, as indicated by some of the significance tests of the data provided. The relevance of the results and the potential of the new variables suggest the need for a stronger 
sample, especially in terms of the registered number of weeks. This would strengthen the statistical range of the results and provide the opportunity to undertake a more complex analysis of the variables used, which have proved feasible and useful as well as original.

\section{Future research}

It would be interesting to carry out an in-depth research into the perceptions of radio presenters and collaborators regarding their own participation in advertising, their level of involvement and influencing factors, and the existing pressures from advertisers and radio owners. Additionally, it would be relevant to analyze the responsibility of radio owners regarding this type of advertising, its production process and broadcast and the factors that influence the pricing policy of RAs. Further studies could focus on the advertisers' knowledge of the legal and deontological limitations that regulate this type of advertising or on the types of pressure advertisers put on radio owners when they demand the collaboration of a specific journalist.

RAs are considered masked marketing practices (Petty \& Andrews, 2008) within hidden or covert advertising in which radio personalities play a special role, while infomercials are an advertising television format very much focused on the sale of products and significantly longer. Nevertheless, over the last few years there has been an important increase in the use of advertorials in television so that it would be interesting to carry out a comparative study on the presence and use of advertorials in both mediums. Comparative studies between countries could also be carried out in order to determine if the results obtained in this work are specific to Spanish radio or can be found elsewhere.

Given the role that journalists play in RAs and their influence on the public as opinion leaders, it would also be relevant to analyze the relationship between advertorial content and the truthfulness of the message endorsed; in other words, the potential deception. The principle of truthfulness should guide all forms of advertising, but especially advertising that uses endorsers as a tool to increase the effectiveness and persuasiveness of the message. In this respect, it would be important to determine the lev- 
el of involvement that journalists have with the text of RAs; whether they can make decisions about the content of the message and whether they demand that advertisers guarantee or substantiate what they have to say about the product or service. It would also be appropriate to undertake an analysis of RA discourse to gain insight into advertising messages that imitate a news item, news reportage or an interview on current affairs.

A further line of research could approach the subject from the perspective of listeners, analyzing their attitude towards these messages and their reaction to them, their perception of radio journalists and how they feel about their advertising collaborations. It would also be of special interest to undertake an experimental study on their ability to distinguish and identify advertorials from other programming contents.

\section{References}

AIMC (Asociación para la Investigación de Medios de Comunicación). (2016). Resumen general del EGM (Estudio General de Medios) [EGM (General Media Study) General Report] (abril 2015 a marzo 2016). Retrieved from http://www.aimc.es/spip.php?action=acceder_document $\&$ arg $=3077 \&$ cle $=28996732$ bec $589 \mathrm{ddba} 1 \mathrm{~b} 4818789266 \mathrm{a}-$ f2af5377d\&file=pdf\%2Fresumegm116.pdf

Autocontrol (Asociación para la Autorregulación de la Comunicación Comercial). (2011). Código de conducta publicitaria [Code of Advertising Conduct]. Retrieved from http://www.autocontrol.es/ pdfs/Cod_conducta_publicitaria.pdf

Baerns, B. (2003). Separating advertising from programme content: The principle and its relevance in communications practice. Journal of Communication Management, 8(1), 101-112. DOI: https://doi. org/10.1108/13632540410807583

Balasubramanian, S. K. (1994). Beyond advertising and publicity: Hybrid messages and public policy issues. Journal of Advertising, 23(4), 29-46. Retrieved from https://www.jstor.org/stable/4188949 
Belch, G. E., \& Belch, M. A. (2013). A content analysis study of the use of celebrity endorsers in magazine advertising. International Journal of Advertising, 32(3), 369-389. DOI: https://doi.org/10.2501/ IJA-32-3-369-389

Berelson, B. (1952). Content analysis in communication research. New York, NY: Hafner Press.

Buchholz, L. M., \& Smith, R. E. (1991). The role of consumer involvement in determining cognitive response to broadcast advertising. Journal of Advertising, 20(1), 4-17. DOI: https://doi.org/10.1080/0 0913367.1991 .10673202

Cameron, G. T., \& Haley, J. E. (1992). Feature advertising: Policies and attitudes in print media. Journal of Advertising, 21(3), 47-55. Retrieved from https://www.jstor.org/stable/4188845

Cameron, G. T., \& Curtin, P. A. (1995). Tracing sources of information pollution: A survey and experimental test of print media's labeling policy for feature advertising. Journalism \& Mass Communication Quarterly, 72(1), 178-189. DOI: https://doi.org/10.1177\% 2F107769909507200115

Cameron, G. T., Ju-Pak, K. H., \& Kim, B. H. (1996). Advertorials in magazines: Current use and compliance with industry guidelines. Journalism \& Mass Communication Quarterly, 73(3), 722-733. DOI: https://doi.org/10.1177\%2F107769909607300316

Cameron, G. T., \& Ju-Pak, K. H. (2000). Information pollution? Labelling and format of advertorials. Newspaper Research Journal, 21 (1), 6576. DOI: https://doi.org/10.1177/073953290002100106

Crook, J. (2004). On covert communication in advertising. Journal of Pragmatics, 36(4), 715-738. DOI: https://doi.org/10.1016/S03782166(03)00039-0 
Dix, S., \& Phau, I. (2009). Spotting the disguises and masquerades: Revisiting the boundary between editorial and advertising. Marketing Intelligence \& Planning, 27(3), 413-427. DOI: https://doi. org/10.1108/02634500910955263

Eckman, A., \& Lindlof, T. (2003). Negotiating the Gray Lines: An ethnographic case study of organizational conflict between advertorials and news. Journalism Studies, 4(1), 65-77. DOI: https://doi. org/10.1080/14616700306507

Ellerbach, J. (2004). The advertorial as information pollution. Journal of Information Ethics, 13(1), 61-75.

Erjavec, K. (2004). Beyond advertising and journalism: Hybrid promotional news discourse. Discourse \& Society, 15(5), 553-578. DOI: https://doi.org/10.1177\%2F0957926504045032

Erjavec, K., \& Kovačič, M. P. (2010). Relations with the media: Who are the main actors in an advertorial production process in Slovenia? Journalism, 11(1), 91-109. DOI: https://doi. org/10.1177\%2F1464884909349581

FTC (Federal Trade Commission). (2009). Guides concerning the use of endorsements and testimonials in advertising. Federal Acquisition Regulation (16 CFR Part 255) Final Rule. Retrieved from https://www. $\mathrm{ftc}$. gov/sites/default/files/documents/federal_register_notices/ guides-concerning-use-endorsements-and-testimonials-advertising-16-cfr-part-255/091015guidesconcerningtestimonials.pdf

Goodlad, N., Eadie, D. R., Kinnin, H., \& Raymond, M. (1997). Advertorial: Creative solution or last resort? International Journal of Advertising, 16(2), 73-84. DOI: https://doi.org/10.1080/02650487. 1997.11104678

Hausknecht, D. R., Wilkinson, J. B., \& Prough, G. E. (1991). Advertorials: Effective? Deceptive? Or tempest in a teapot? Akron Business and Economic Review, 22(4), 41-52. 
Harro-Loit, H., \& Saks, K. (2006). The diminishing border between advertising and journalism in Estonia. Journalism Studies, 7(2), 312-322. DOI: https://doi.org/10.1080/14616700500533635

ICC (International Chamber of Commerce). (2011). Consolidated ICC Code of Advertising and Marketing Communication Practice. Retrieved from http://www.codescentre.com/media/2083/660\%20 consolidated\%20icc\%20code_2011_final\%20with\%20covers.pdf

Ju-Pak, K. H., Kim, B. H., \& Cameron, G. T. (1995). Trends in the use and abuse of advertorials in magazines. Mass Comm Review, 22 (34), 112-128.

Kertz, C. L., \& Ohanian, R. (1992). Source credibility, legal liability, and the law of endorsements. Journal of Public Policy \& Marketing, 11(1), 12-23. Retrieved from https://www.jstor.org/stable/30000021

Kim, B. H., Pasadeos, Y., \& Barban, A. (2001). On the deceptive effectiveness of labeled and unlabeled advertorial formats. Mass Communication \& Society, 4(3), 265-281. DOI: https://doi.org/10.1207/ S15327825MCS0403_02

Lacher, K. T., \& Rotfeld, H. J. (1994). Newspaper policies on the potential merging of advertising and news content. Journal of Public Policy \& Marketing, 13(2), 281-289. Retrieved from https://www.jstor. org/stable/30000403

Martin, B. A., Bhimy, A. C., \& Agee, T. (2002). Infomercials and advertising effectiveness: An empirical study. Journal of Consumer Marketing, 19(6), 468-480. DOI: https://doi. org/10.1108/07363760210444850

Muela-Molina, C. (2010). La representación de los géneros informativos en la publicidad radiofónica [The representation of informative genres 
in radio advertising]. Sphera Pública, (10), 167-178. Retrieved from http://www.redalyc.org/articulo.oa?id=29719345011

Muela-Molina, C. (2012). La representación de la ficción en la cuña publicitaria. Personajes, contextos y otros elementos narrativos. Área Abierta, 31(1), 1-15. DOI: https://doi.org/10.5209/rev_ ARAB.2012.v31.38969

Muela-Molina, C., Martín-Santana,J.D., \& Reinares-Lara, E. (2018).Journalists as radio advertising endorsers in news or talk radio stations. Journalism. DOI: https://doi.org/10.1177\%2F1464884917753785

Nebenzhal, I. D., \& Jaffe, E. D. (1998). Ethical dimensions of advertising executions. Journal of Business Ethics, 17(7), 805-815. Retrieved from https://www.jstor.org/stable/2507312

Neuendorf, K. A. (2002). The content analysis guidebook (Vol. 300). Thousand Oaks, CA: SAGE Publications.

OfCom (Office of Communications). (2011). Guidance notes. Section Ten: Commercial communications in radio programming. Retrieved from http://stakeholders.ofcom.org.uk/binaries/broadcast/guidance/831193/section10.pdf

Perelló-Oliver, S., \& Muela-Molina, C. (2012). La publicidad radiofónica en España y el perfil socio-demográfico de su audiencia. Palabra Clave, 15(2), 224-251.DOI: http://doi.org/10.5294/pacla.2012.15.2.2

Perello-Oliver, S., \& Muela-Molina, C. (2017). Radio mentions: An analysis of radio personalities and ethical behavior. International Journal of Communication, 11, 3566-3586. Retrieved from https:// ijoc.org/index.php/ijoc/article/view/7177

Petty, R. D., \& Andrews, J. C. (2008). Covert marketing unmasked: A legal and regulatory guide for practices that mask marketing messag- 
es. Journal of Public Policy \& Marketing, 27(1), 7-18. DOI: http:// dx.doi.org/10.1509/jppm.27.1.7

Poler Kovačič, M., \& Erjavec, K. (2010). Production process of unlabeled advertorials in the Slovenian press. Communications, 35(4), 375395. DOI: https://doi.org/10.1515/comm.2010.020

Poler Kovačič, M., Erjavec, K., \& Stular, K. (2011). Unlabelled advertorials in Slovenian life-style press: A study of the promotion of health products. Communication \& Medicine, 8(2), 157-168.DOI: http:// dx.doi.org/10.1558/cam.v8i2.157

Priester, J. R., \& Petty, R. E. (2003). The influence of spokesperson trustworthiness on message elaboration, attitude strength, and advertising effectiveness. Journal of Consumer Psychology, 13(4), 408-421. DOI: https://doi.org/10.1207/S15327663JCP1304_08

Rozukalne, A. (2012). Hidden advertising in Latvian media content: Reasons, editorial strategies and advertiser practice. Communication Sciences, 13-26. Retrieved from http://www.rsu.lv/eng/images/ Documents/Publications/2011_research_articles_soc_eng.pd$\mathrm{f} \#$ page $=13$

Sandler, D. M., \& Secunda, E. (1993). Point of view: Blurred boundaries--where does editorial end and advertising begin? Journal of $A d-$ vertising Research, 33(3), 73-80.

Singh, M., Balasubramanian, S. K., \& Chakraborty, G. (2000). A comparative analysis of three communication formats: Advertising, infomercial, and direct experience. Journal of Advertising, 29(4), 59-75. Retrieved from https://www.jstor.org/stable/4189161

Society of Professional Journalists. (2014). Code of ethics. Retrieved from http://www.spj.org/ethicscode.asp 
Steininger, C., \& Woelke, J. (2008). Separating TV ads from TV programming. What we can learn about program-integrated advertising from economic theory and research on media use. Communications, 33(4), 455-471. DOI: http://dx.doi.org/10.1515/ COMM.2008.028

Stout, P. A., Wilcox, G. B., \& Greer, L. S. (1989). Trends in magazine advertorial use. Journalism \& Mass Communication Quarterly, 66(4), 960 964. DOI: https://doi.org/10.1177\%2F107769908906600430

Van Reijmersdal, E., Neijens, P., \& Smit, E. (2005). Readers' reactions to mixtures of advertising and editorial content in magazines. Journal of Current Issues \& Research in Advertising, 27(2), 39-53. DOI: https://doi.org/10.1080/10641734.2005.10505180

Wilkinson, J. B., Hausknecht, D. R., \& Prough, G. E. (1995). Reader categorization of a controversial communication: Advertisement versus editorial. Journal of Public Policy \& Marketing, 14(2), 245-254. DOI: https://doi.org/10.1177\%2F074391569501400206

Zhou, S. (2012). 'Advertorials': A genre-based analysis of an emerging hybridized genre. Discourse \& Communication, 6(3), 323-346. DOI: https://doi.org/10.1177\%2F1750481312446265 